\title{
USING ELEARNING AND INTERNATIONAL COLLABORATION AMONG UNIVERSITIES TO PREPARE TEACHERS OF CHINESE AS A FOREIGN LANGUAGE
}

\author{
Lih-Ching Chen Wang \\ Ph.D., Professor, Educational Technology in the Department of Curriculum and Foundations \\ Director/Founder, Chinese Teacher Licensure M.A. Program \\ Coordinator/Founder, Urban Education Ph.D. Program with a Specialization in \\ "Teaching Chinese as a Foreign Language" \\ College of Education and Human Service, Cleveland State University \\ 2121 Euclid Ave., JH386, Cleveland, OH 44115-2214, U.S.A.
}

\begin{abstract}
With the growth and international expansion of the Internet has come a corresponding growth in eLearning. Colleges and universities throughout the globe have incorporated eLearning as an increasingly important part of their activities, and a predictable consequence has been increased interest in international collaboration among colleges and universities to solve common problems in higher education. This paper describes the successful international collaboration by building activities of one United States public university, working with partners in China and Taiwan to address needs for enrollment, expanded course offerings, and new degree programs to meet an identified demand for teachers of Chinese as a foreign language in multiple settings.
\end{abstract}

\section{KEYWORDS}

eLearning, Collaboration, International, Mandarin Chinese, Foreign Language Instruction

\section{INTRODUCTION}

The rise of the Internet as a global platform for eLearning in the 21st century has had a profound effect on higher education. Teaching and learning activities have become available to anyone with an Internet connection, anytime, and anywhere (Cifuentes \& Shih, 2001). eLearning has become a standard component in the offerings of higher education institutions (Ellis, Ginns, \& Piggott, 2009; Arkorful \& Abaidoo, 2014; Clover, 2017). This has helped colleges and universities provide for a more diverse student body, both in terms of geography and in terms of age (O'Neill, Singh, \& O'Donoghue, 2004). In the process these institutions have expanded their global reach in search of new students and international reputations (Singh, O'Donoghue, \& Worton, 2005). To do so has required international collaboration, which is complicated at best (Wang \& Beasley, 2014) but has the potential to enhance activities that are fundamental to the existence of colleges and universities (McLoughlin, Wang, \& Beasley, 2008). Successful international collaboration via eLearning has supported the maintenance (and sometimes increase) of needed student enrollment, expansion of course offerings, and even the development of entire new degree programs.

The purpose of this paper is to share some eLearning examples implemented in the author's working university in the Midwestern United States. Please note that the model for using eLearning in the author's institution is wholly online (as specified by Arkorful \& Abaidoo, 2014, p. 404). 


\section{CONTEXT}

The following is an account of how a public university in the United States developed successful international collaboration using eLearning that benefited students in institutions in higher education among the United States, China, and Taiwan.

About 14 years ago, a public university in the United States came to have a strong interest in collaboration with universities in other countries for three main reasons:

1) Enrollment. Every university is interested in boosting enrollment, and international students provided a promising pool of potential applicants.

2) Expanded course offerings. No university has faculty and resources to offer every possible course in every field. Partnerships could increase available course offerings, thereby potentially increasing enrollments and revenue.

3) Creating something new. Working with international partners could make it possible to accomplish things that neither entity could accomplish alone. (This ultimately became a quest for new degree and certification programs.)

These three items became the primary goals of an ultimately successful project that would span the next 14 years. This is an account of that project - what actions were taken, what obstacles were encountered, and how problems were solved.

It all began in approximately15 years ago when the author of this proposal received an invitation to deliver several professional presentations in China. She soon invited the Dean of her college and other faculty and administrators from her home institution to China, and began to stimulate interest in various forms of international collaboration - faculty exchange, jointly sponsored conferences, visits, and international collaboration between K-12 institutions. Two years later she was successful in securing a Fulbright Scholarship to Taiwan, and her time spent at a university there allowed her to cultivate additional professional contacts with institutions in both China and Taiwan. That process continued in the ensuing years.

About the same time, the U.S. government had made available three years of funding through the CORE program for training teachers of critical languages - and Mandarin Chinese was one of these languages. Her home university successfully secured funding to offer classes leading to such certification; they recruited native Chinese speakers in their geographic area, trained them in pedagogical techniques, and secured state teaching licensure for the individuals as teachers of Chinese. But the federal funding ended after three years. The experience demonstrated that there was a large demand for such a program, and there was at that time no replacement program to continue meeting the demand.

The author of this paper saw an opportunity. She created a graduate program aimed at native speakers of Chinese which led to a combination of a Master's degree in education with state teaching licensure in the area of Chinese language. It took three years to secure all of the approvals, but the program launched in Spring 2011 and continues to this day. In order to meet all ACTFL standards for teacher education candidates, the degree included a requirement for evidence of appropriate coursework in Chinese culture, literature, and linguistics. The U.S. home university lacked courses or faculty in these areas - but as it turned out, institutions with which connections had been established in both China and Taiwan had existing courses in these areas and were willing to provide them via eLearning. They began doing so in 2011 and continue doing so in the present. The program was an immediate success. Enrollment has been steady since its inception, and nearly every graduate who sought a teaching position has been able to find a job placement teaching Chinese in the U.S.

At this point we should note that those three initial goals were met (in some form) at this stage. Students were enrolling in the local university in the U.S. who might never have done so without this program. The available course offerings had been expanded to include eLearning courses in Chinese culture, literature, and linguistics, with the support of Chinese and Taiwanese partner universities. And the local university in the U.S., working with multiple partners overseas, had created an entire new graduate degree/teaching licensure program.

This was noticed. The author formed a delegation led by the local university President in the U.S. to visit with institutional partners in China. At the encouragement of the author, the possibility was raised of "upping the ante" - creating a program that would not only prepare teachers of Chinese as a foreign language, but would instead prepare individuals to prepare teachers of Chinese as a foreign language. That is, a doctoral program, that could graduate individuals capable of creating and maintaining their own programs for preparing teachers of Chinese as a foreign language. At about the same time, the students graduating from the earliest cohorts in 
the local Master's degree/licensure program were voicing an interest in being able to continue their studies. This also pointed toward a doctoral program. The author began the process of formally proposing and securing approval for such a doctoral program.

Fast forward (since securing approval for doctoral level programs is exponentially more complicated than doing so for Master's level programs) to 2017. Final approval was secured for a Ph.D. program in Urban Education, with a specialization in "Teaching Chinese as a Foreign Language". The required coursework includes four graduate courses supported by two partner universities in China. In Fall 2018, the program admitted its first student.

We can now step back and say that the three initial goals have been met a second time, at a higher level. Doctoral students are now enrolling at the local institution in the U.S. who would have been unlikely to do so prior to the establishment of this doctoral degree specialization program. Course offerings have been further expanded, to include four at the doctoral level offered via eLearning by Chinese partner institutions. And the collaboration has again produced something new, this time at an even higher level - a doctoral program specialization engaged in turning out future leaders in the field of teaching Chinese as a foreign language.

\section{CONCLUSION}

In summary, this account has described the process through which a Midwestern public university in the United States was able to make use of eLearning and international collaboration to address concerns common to all universities everywhere: enrollment, course offerings, and the ongoing drive to create and nurture new scholarly endeavors.

\section{REFERENCES}

Arkorful, V., \& Abaidoo, N. (2014). The role of e-learning, the advantages and disadvantages of its adoption in higher education. International Journal of Education and Research, 2(12), 397-410.

Cifuentes, L., \& Shih, Y. D. (2001). Teaching and learning online: A collaboration between U.S. and Taiwanese students. Journal of Research on Computing in Education, 33(4), 456-474.

Clover, I. (2017). Advantages and disadvantages of eLearning. Retrieved from https://elearningindustry.com/advantagesand-disadvantages-of-elearning

Ellis, R. A., Ginns, P., \& Piggott, L. (2009). E-learning in higher education: Some key aspects and their relationship to approaches to study. Higher Education Research \& Development, 28(3), 303-318.

McLoughlin, J. A., Wang, L. C., \& Beasley, W. A. (2008). Transforming the college through technology: A change of culture. Innovative Higher Education, 33(2), 99-109.

O’Neill, K., Singh, G., \& O’Donoghue, J. (2004). Implementing eLearning programmes for higher education: A review of the literature. Journal of Information Technology Education, 3(1), 313-323.

Singh, G., O'Donoghue, J., \& Worton, H. (2005). A study into the effects of eLearning on higher education. Journal of University Teaching \& Learning Practice, 2(1), 13-24.

Wang, L. C., \& Beasley, W. (2014). International collaboration in higher education between the United States and China: Differences in cultural perspective. International Journal of Continuing Education and Lifelong Learning, 7(1), 47-57. 